\title{
Une vaste étendue où l'on pouvait entrer partout
}

\section{Anne Oterholm}

Traducteur : Karin Holter

\section{OpenEdition}

Journals

Édition électronique

URL : http://journals.openedition.org/ccs/686

DOI : $10.4000 /$ ccs.686

ISSN : 2558-782X

Éditeur :

Presses universitaires de Rennes, Association des lecteurs de Claude Simon

Édition imprimée

Date de publication : 31 décembre 2010

Pagination : 167

ISBN : 9782354120771

ISSN : $1774-9425$

\section{Référence électronique}

Anne Oterholm, « Une vaste étendue où l'on pouvait entrer partout », Cahiers Claude Simon [En ligne], 6। 2010, mis en ligne le 21 septembre 2017, consulté le 15 septembre 2020. URL : http:// journals.openedition.org/ccs/686 


\title{
Une vaste étendue où l'on pouvait entrer partout
}

\author{
Par Anne OTERHOLM
}

Pour moi, la lecture de La Route des Flandres est presque devenue une obsession. J'aurais pu tout simplement rester dans ce livre, y rester et y rester encore. Il donnait la permission de ne plus penser. Tu pouvais entrer dans le livre n'importe où. Le texte était massif et non-linéaire. Comme un espace énorme, avec des phrases interminables, sans commencement ni fin.

Si Simon a eu de l'importance pour ma propre façon d'écrire ? Tout d'abord parce que chez Simon, j'ai fait la rencontre d'un texte qui me disait que tout est possible. Tout est permis. Pour moi aussi. C'est merveilleux qu'on vous rappelle justement ça! Cela comporte une liberté quasiment sans limites. 